\title{
Defisiensi Besi dan Anemia Defisiensi Besi pada Anak Remaja Obes
}

\author{
Aryono Hendarto, Rhyno Febriyanto, Risma K. Kaban \\ Departemen Ilmu Kesehatan Anak Fakultas Kedokteran Universitas Indonesia/Rumah Sakit Dr. Cipto Mangunkusumo, \\ Jakarta
}

Latar belakang. Remaja merupakan kelompok risiko tinggi untuk mengalami defisiensi besi. Obesitas pada remaja meningkatkan risiko defisiensi besi akibat perbedaan pola asupan dan inflamasi kronik derajat rendah.

Tujuan. Mengetahui status besi dan asupan besi remaja obes usia 15-17 tahun.

Metode. Penelitian potong lintang pada remaja usia 15 - 17 tahun di dua SMU Jakarta Pusat pada bulan September - November 2015. Subjek dibagi menjadi 2 kelompok berdasarkan indeks massa tubuh (IMT). Subjek dinyatakan obes bila IMT $\geq \mathrm{P}_{95}$ dan nonobes bila IMT $\geq \mathrm{P}_{5}-<\mathrm{P}_{85}$. Kepada subjek dilakukan penilaian status besi, yaitu hemoglobin, mean corpusculus volume (MCV), besi serum, feritin, saturasi transferin, dan total iron bonding capacity (TIBC) serta analisis diet.

Hasil. Sebanyak 100 subyek memenuhi kriteria inklusi yang terdiri dari 52 subjek obes dan 48 subjek non-obes. Tidak terdapat perbedaan bermakna proporsi defisiensi besi dan anemia defisiensi besi pada kelompok obes dan non-obes $(9,6 \%$ vs $16,7 \%$; $\mathrm{p}=0,295)$. Tidak terdapat perbedaan bermakna asupan zat besi total kelompok obes dan non-obes $(8(2,6-95,9) \mathrm{mg} / \mathrm{hari}$ vs $10(1,8-83,4)$ $\mathrm{mg} /$ hari; $\mathrm{p}=0,188)$. Persentase asupan zat besi hem kelompok obes lebih tinggi dibandingkan kelompok non-obes $(31(0,0-95,6) \%$ vs $20(15,2-100,0) \% ; p=0,029)$.

Kesimpulan. Tidak terdapat perbedaan proporsi defisiensi besi dan anemia defisiensi besi pada remaja obes dan non obes usia $15-17$ tahun. Tidak terdapat perbedaan rerata asupan zat besi remaja obes dan non-obes usia 15 - 17 tahun. Sari Pediatri 2018;20(1):1-6

Kata kunci: defisiensi besi, anemia defisiensi besi, asupan zat besi, remaja, obesitas

\section{Iron Deficiency and Iron Deficiency Anemia in Obese Adolecents}

Aryono Hendarto, Rhyno Febriyanto, Risma K. Kaban

Background. Adolescence is a high-risk group for iron deficiency. Obesity can increase the risk of iron deficiency due to low iron intake and low grade chronic inflammation.

Objective. To assess profil and intake iron in obese adolescents aged 15 to 17 years old.

Methods. Cross-sectional study on adolescents aged 15 to 17 years old in Senior High School in Central Jakarta between September to November 2015. Subjects were divided into 2 groups based on body mass index (BMI). Obese group if BMI $\geq \mathrm{P}_{95}$ and non-obese group if $\mathrm{BMI} \geq \mathrm{P}_{5}-<\mathrm{P}_{85}$. We measured iron status included hemoglobin, mean corpuscular volume (MCV), serum iron, ferritin, transferrin saturation, and total iron binding capacity (TIBC). Dietary iron intakes were measured by food recall.

Results. There were 100 subjects that met the eligibility criteria. There was no significance difference in the proportion of iron deficiency and iron deficiency anemia between obese and non-obese groups (9.6\% vs $16.7 \%$; $=0.295)$. Both groups did not significantly differ in total iron intake $(8(2.6-95.9) \mathrm{mg} /$ day vs $10(1.8-83.4) \mathrm{mg} / \mathrm{day} ; \mathrm{p}=0.188)$. Obese groups have higher heme iron intake than non-obese groups $(31(0.0-95.6) \%$ vs $20(15.2-100.0) \%$; $\mathrm{p}=0.029)$.

Conclusions. The proportions of iron deficiency and iron deficiency anemia were the same in both adolescence group. There was no difference in iron intake in obese and non-obese adolescents. Sari Pediatri 2018;20(1):1-6

Keywords: iron deficiency, iron deficiency anemia, iron intake, adolescence, obesity

Alamat korespondensi: Aryono Hendarto. Departemen Ilmu Kesehatan Anak Fakultas Kedokteran Universitas Indonesia/Rumah Sakit Dr. Cipto Mangunkusumo, Jakarta. Email: aryhendarto@yahoo.com; arynebraska@gmail.com 
A

nemia defisiensi besi (ADB) merupakan salah satu masalah kesehatan utama di Indonesia. Menurut Riset Kesehatan Dasar Tahun (Riskesdas) tahun 2013, sekitar $17,3 \%$ remaja usia 13-18 tahun yang tinggal di daerah urban mengalami ADB. ${ }^{1}$ Remaja merupakan kelompok risiko tinggi mengalami defisiensi besi (DB). Badan Kesehatan Dunia WHO melaporkan bahwa kebutuhan besi pada usia remaja lebih tinggi dibanding kelompok usia lain. Hal tersebut disebabkan aktivitas yang meningkat, haid, dan kebutuhan basal zat besi yang tinggi. ${ }^{2}$ Peningkatan prevalensi obesitas pada periode belakangan ini harus sudah menjadi perhatian semua pihak terkait. ${ }^{3,4}$ Pada Riskesdas tahun 2013 dilaporkan angka prevalensi obesitas remaja usia 16-18 tahun di Jakarta sebesar 11,5\%. ${ }^{1}$ Beberapa penelitian menunjukkan hubungan antara obesitas dengan insiden anemia defisiensi besi. ${ }^{5-7}$

Penelitian di Israel ditunjukkan bahwa pengonsumsi diet tinggi makronutrien (karbohidrat dan lemak), tetapi rendah mikronutrien (zat besi) adalah anak obes. ${ }^{5}$ Pada anak obes, penyebab lain $\mathrm{ADB}$ adalah inflamasi kronik derajat rendah yang dimediasi oleh hepsidin yang menyebabkan hambatan absorpsi zat besi di saluran intestinal dan retensi zat besi di sistem retikuloendotelial. ${ }^{7-9}$ Di Amerika Serikat, Israel, dan Swiss, prevalensi ADB anak obes usia 2-16, 3-19, 6-14 tahun berturut-turut 5,5\%, 38,8\%, dan 20\%. ${ }^{10}$ Prevalensi ADB anak obes sangat bervariasi, tetapi pada usia remaja belum banyak dilaporkan. Individu obes seringkali diasumsikan memiliki status nutrisi termasuk mikronutrien yang lebih baik dibandingkan individu non-obes. Namun faktanya, remaja obes berisiko tinggi mengalami ADB karena asupan besi yang rendah, kebutuhan besi meningkat, dan mengalami inflamasi kronik derajat rendah. ${ }^{5,6,10}$ Penelitian ini bertujuan untuk meningkatkan kepedulian terhadap kemungkinan terjadinya $\mathrm{ADB}$ pada remaja obes.

\section{Metode}

Penelitian cross sectional ini dilakukan pada bulan September sampai dengan bulan November 2015 yang melibatkan 52 subjek obes dan 48 subjek non-obes yang berasal dari 2 Sekolah Menengah Atas (SMA) di wilayah Jakarta Pusat. Kriteria inklusi, yaitu anak usia 15-17 tahun yang mengalami obesitas. Kriteria eksklusi meliputi remaja yang mengalami obesitas sekunder, infeksi (demam, batuk, pilek dan diare), talasemia, tuberkulosis, penyakit ginjal, mengonsumsi steroid atau mengalami kenaikan berat badan akibat obat, menstruasi, dan merokok. Status nutrisi ditentukan berdasarkan indeks masa tubuh (IMT) menurut kurva pertumbuhan CDC 2000. Dikategorikan obesitas jika IMT $\geq \mathrm{P}_{95}$ dan non-obes jika IMT berada pada $\mathrm{P}_{5}$ hingga $\mathrm{P}_{85}{ }^{11}$ Kategori defisiensi besi jika memenuhi minimal 2 dari 5 kriteria objektif yaitu: MCV $<78$ pg; kadar feritin $<15 \mu \mathrm{g} / \mathrm{L}$; kadar besi serum $\leq 50 \mu \mathrm{g} /$ dL; saturasi transferrin $<15 \%$; dan kadar TIBC $>390$ $\mu \mathrm{g} / \mathrm{dL} .{ }^{2,12}$ Anemia defisiensi besi dan DB ditentukan dengan pemeriksaan kadar hemoglobin $(\mathrm{Hb})$, mean corpuscular volume (MCV), besi serum, feritin, saturasi transferrin, dan total iron binding capacity (TIBC). Asupan makanan (asupan besi total, hem dan non-hem) ditentukan dengan metode food recall yang dilakukan oleh dietisien terlatih dan dianalisis menggunakan program NutriSurvey ${ }^{\oplus}$. Persentase zat besi heme dan non-heme di tentukan berdasarkan konsumsi besi. Nilai normal asupan besi mengacu pada rekomendasi Badan Kesehatan Dunia 2001 yaitu untuk remaja laki-laki usia 15-17 tahun sebanyak 12,5 $-37,6 \mathrm{mg} /$ hari dan untuk remaja perempuan sebanyak $20,7-62,0 \mathrm{mg} / \mathrm{hari}$ bergantung pada bioavailabilitas dari ferrous. Data diproses menggunakan Statistical Package for Social Science (SPSS) version 20, selanjutnya deskrispi data ditampilkan dengan nomor dan presentase. Penelitian ini mendapatkan persetujuan kaji etik dari Komite Etik Fakultas Kedokteran Universitas Indonesia.

\section{Hasil}

Sebanyak 131 subjek berpartisipasi dalam penelitian ini, tetapi hanya 100 subjek yang memenuhi kriteria inklusi karena 31 subjek dieksklusi dengan berbagai alasan. Subjek terdiri dari 52 remaja obes dan 48 remaja non-obes sebagai kontrol.

Proporsi subjek perempuan lebih banyak di bandingkan lelaki. Rerata berat badan (BB) dari semua subjek 60,5 (SD 18,1) kg dan rerata tinggi badan (TB) $162,3($ SD 8,1) cm. Nilai tengah IMT dari semua subjek 26,9 (antara 17,3 - 44,2) $\mathrm{kg} / \mathrm{m}^{2}$. Distribusi klasifikasi antropometrik berdasarkan obes dan nonobes tertera pada Tabel 1.

Data menunjukkan rerata nilai $\mathrm{Hb}$ dari semua subjek adalah 14 (SD 1,8) g/dL (SD 1,8), rerata kadar 
Tabel 1. Karakteristik subjek penelitian

\begin{tabular}{lcc}
\hline Karakteristik & $\begin{array}{c}\text { Obes } \\
\mathrm{n}=52\end{array}$ & $\begin{array}{c}\text { Non-obes } \\
\mathrm{n}=48\end{array}$ \\
\hline Jenis kelamin (\%) & & \\
$\quad$ Lelaki & $25(48)$ & $24(50)$ \\
$\quad$ Perempuan & $27(52)$ & $24(50)$ \\
Usia (tahun), nilai tengah (rentang) & $17(15-17,9)$ & $17(15-17,8)$ \\
Antropometrik & & \\
$\quad$ BB (kg), nilai tengah (rentang) & $81(59,1-121,8)$ & $54(41-83)$ \\
TB (cm), nilai rerata (SD) & $(\mathrm{SD} \mathrm{8,2)}$ & $161(\mathrm{SD} 7,9)$ \\
IMT (kg/m ${ }^{2}$ ), nilai rerata (SD) & $31(\mathrm{SD} \mathrm{3,8)}$ & $21(\mathrm{SD} 2,2)$ \\
Persentil IMT, nilai tengah (rentang) & $99(95-100)$ & $46(5,3-84,4)$ \\
\hline
\end{tabular}

Tabel 2. Profil hematologi subjek obes dan non-obes

\begin{tabular}{lccc}
\hline Variabel & $\begin{array}{c}\text { Obess } \\
\mathrm{n}=52\end{array}$ & $\begin{array}{c}\text { Non-obes } \\
\mathrm{n}=48\end{array}$ & Nilai $\mathrm{p}$ \\
\hline $\mathrm{Hb}(\mathrm{g} / \mathrm{dL})$, rerata $(\mathrm{SD})$ & $14(1,7)$ & $14(1,9)$ & $0,324^{\mathrm{a}}$ \\
$\mathrm{Ht}(\%)$, rerata $(\mathrm{SD})$ & $44(4,6)$ & $43(4,7)$ & $0,225^{\mathrm{a}}$ \\
$\mathrm{MCV}(\mathrm{pg})$, nilai tengah (range) & $84(69,1-93,3)$ & $85(62,5-93,1)$ & $0,692^{\mathrm{b}}$ \\
Serum besi $(\mu \mathrm{g} / \mathrm{dL})$, rerata $(\mathrm{SD})$ & $87(30,4)$ & $89(36,5)$ & $0,786^{\mathrm{a}}$ \\
TIBC $(\mu \mathrm{g} / \mathrm{dL})$, rerata $(\mathrm{SD})$ & $327(44,7)$ & $331(46,6)$ & $0,726^{\mathrm{a}}$ \\
Serum ferritin $(\mu \mathrm{g} / \mathrm{L})$, nilai tengah (range) & $74(7,3-223,9)$ & $60(1,3-226,2)$ & $0,069^{\mathrm{b}}$ \\
Saturasi transferrin $(\%)$, rerata $(\mathrm{SD})$ & $27(9,6)$ & $28(12,0)$ & $0,725^{\mathrm{a}}$ \\
\hline
\end{tabular}

${ }^{a}$ Unpaired T-test; ${ }^{\mathrm{b}}$ Uji Mann Whitney

Tabel 3. Distribusi status besi subjek

\begin{tabular}{lccc}
\hline Variabel & $\begin{array}{c}\text { Obes } \\
\mathrm{n}=52\end{array}$ & $\begin{array}{c}\text { Non-obes } \\
\mathrm{n}=48\end{array}$ & Nilai $\mathrm{p}$ \\
\hline Normal, n (\%) & $47(90)$ & $40(83)$ & $0,295^{\text {a }}$ \\
Defisiensi besi, $\mathrm{n}(\%)$ & $3(6)$ & $1(2)$ & \\
Anemia defisiensi besi, $\mathrm{n}(\%)$ & $2(4)$ & $7(15)$ & \\
Total, $\mathrm{n}(\%)$ & $52(100)$ & $48(100)$ & \\
\hline
\end{tabular}

${ }^{a}$ Uji Chi-squre dilakukan dengan menggabungkan kedua kelompok defisiensi besi dan anemia defisiensi besi

besi serum 88,2 (SD 33,3) $\mu \mathrm{g} / \mathrm{dL}$, rerata kadar TIBC $329(\mathrm{SD} 45,4) \mu \mathrm{g} / \mathrm{dL}$, rerata saturasi transferin 27,5 (SD 10,8)\%, dan nilai tengah kadar ferritin 66,8 (1,3 $-226,2) \mu \mathrm{g} / \mathrm{L}$. Tabel 2 menunjukkan profil hematologi subjek obes dan non-obes.

Penelitian ini menunjukkan prevalensi defisiensi besi adalah $4 \%$, sedangkan prevalensi anemia defisiensi besi $9 \%$. Data menunjukkan seluruh subjek yang mengalami defisiensi besi dan anemia defisiensi besi adalah remaja perempuan. Distribusi status besi subjek tertera pada Tabel.
Mengingat ada sel dalam Tabel 3 yang mempunyai nilai expected count di bawah 5 maka pada analisis selanjutnya peneliti menggabungkan kelompok defisiensi besi dan anemia defisiensi besi menjadi satu kelompok.

Sumber utama asupan besi berasal dari protein, terutama protein hewani. Nilai tengah persentase asupan protein subjek adalah $12 \%$ (rentang 6-31\%). Berdasarkan angka kecukupan gizi (AKG), 88\% subjek mempunyai asupan protein rendah, $10 \%$ cukup, dan $2 \%$ lebih. Tidak ada perbedaan asupan protein antara subjek obes dan non-obes (Tabel 4) 
Aryono Hendarto dkk: Defisiensi besi dan anemia defisiensi besi pada anak remaja obes

Tabel 4. Proporsi asupan protein remaja obes dan non-obes

\begin{tabular}{lccc}
\hline Asupan protein & Obes & Non-obes & Nilai $\mathrm{p}$ \\
\hline Kurang, $\mathrm{n}(\%)$ & $45(87)$ & $\mathrm{n}=48$ & $0,219^{\mathrm{a}}$ \\
Cukup, $\mathrm{n}(\%)$ & $6(11)$ & $37(77)$ & \\
Tinggi, $\mathrm{n}(\%)$ & $1(2)$ & $10(21)$ & \\
\hline Total, $\mathrm{n}(\%)$ & $52(100)$ & $48(100)$ & \\
${ }^{\mathrm{a}}$ Uji Chi-squre dilakukan dengan menggabungkan kedua kelompok defisiensi besi dan anemia defisiensi besi.
\end{tabular}

Tabel 5. Perbandingan nilai tengah asupan besi antara remaja obes dan non-obes

\begin{tabular}{lccc}
\hline Variabel & $\begin{array}{c}\text { Obes } \\
\mathrm{n}=52\end{array}$ & $\begin{array}{c}\text { Non-Obes } \\
\mathrm{n}=48\end{array}$ & Nilai $\mathrm{p}$ \\
\hline Total besi (mg/hari), nilai tengah (rentang) & $8(2,6-95,9)$ & $10(1,8-83,4)$ & 0,188 \\
Besi hem (mg/hari), nilai tengah (rentang) & $2(0,0-91,6)$ & $2(0,0-23,0)$ & 0,336 \\
Besi non-hem (mg/hari), nilai tengah (rentang) & $5(1,5-31,7)$ & $7(1,5-82,9)$ & 0,159 \\
Presentase besi hem (\%), nilai tengah (rentang) & $31(0-95,6)$ & $20(0-84,8)$ & $0,029^{*}$ \\
\hline
\end{tabular}

${ }^{\bar{P}}$ Uji Mann Whitney; $\mathrm{p}<0,05$

Pada seluruh subjek ditemukan nilai tengah konsumsi besi total 9,5 (1,8-95,9) $\mathrm{mg} /$ hari, asupan besi hem 2,2 $(0,0-91,6) \mathrm{mg} / \mathrm{hari}$, asupan besi nonhem 5,9 $(1,5-82,9) \mathrm{mg} /$ hari, persentase besi hem $28,6(0,0-95,6) \%$ dan persentase besi non-hem 71,4 $(4,4-100,1) \%$. Perbandingan nilai tengah asupan besi antara remaja obes dan non-obes tertera pada Tabel 5 .

\section{Pembahasan}

Pada remaja obes, defisiensi besi dapat disebabkan oleh asupan zat besi yang rendah, malabsorpsi besi, kurang aktivitas fisik, kebutuhan besi meningkat, dan proses inflamasi kronik derajat rendah. ${ }^{13}$ Berdasarkan rekomendasi Badan Kesehatan Dunia WHO tahun 2001, asupan zat besi yang normal untuk anak lelaki berusia 15-17 tahun adalah 12,5-37,6 mg/hari dan untuk anak perempuan adalah 20,7-62,0 mg/hari, tergantung pada bioavailabilitas zat besi. ${ }^{2}$ Kebutuhan besi berdasarkan rekomendasi Kementerian Kesehatan tahun 2013 untuk anak lelaki berusia 15-17 tahun adalah $15 \mathrm{mg} /$ hari dan $26 \mathrm{mg} /$ hari untuk anak perempuan. ${ }^{14}$

Meskipun hasil penelitian secara statistik tidak bermakna, didapatkan proporsi asupan besi pada remaja obes lebih tinggi dibandingkan remaja nonobes. Hasil tersebut berbeda dengan penelitian di luar negeri yang menyatakan bahwa tidak ada perbedaan yang bermakna antara asupan besi pada kelompok obesitas dan non-obesitas. ${ }^{10} \mathrm{Hal}$ tersebut disebabkan konsumsi besi hem lebih tinggi pada kelompok obes dibandingkan kelompok non-obes. Sumber zat besi hem, seperti daging atau unggas memiliki bioavailabilitas lebih tinggi daripada besi non-hem. Besi hem dapat diserap langsung oleh enterosit dan tidak terpengaruh oleh interaksi makanan. ${ }^{15,16}$ Penyerapan zat besi non-hem meningkat dengan zat penambah, seperti vitamin $\mathrm{C}$, dan menurun dengan zat penghambat seperti teh, asam fitrat, dan kalsium. ${ }^{17}$ Kami tidak menemukan perbedaan antara asupan vitamin $\mathrm{C}$, asam fitat, teh, kopi, dan susu pada kelompok remaja obes dan non-obes (hasil tidak ditunjukkan pada tabel). Hal tersebut menyebabkan proporsi kekurangan zat besi pada kelompok remaja obes rendah dibandingkan remaja yang non-obes.

Hasil penelitian kami memperlihatkan proporsi defisiensi besi pada remaja obes lebih rendah dibandingkan dengan remaja non-obes, tetapi pada uji statistik tidak menunjukkan perbedaan bermakna. Hasil penelitian kami berbeda dengan penelitian lain di berbagai negara yang menunjukkan proporsi defisiensi besi lebih besar pada kelompok obes dibandingkan kelompok non-obes. ${ }^{5,10,15}$ Perbedaan hasil tersebut mungkin disebabkan, antara lain, karena sebaran jenis kelamin yang tidak merata serta perbedaan kriteria penegakan diagnosis defisiensi besi dan anemia defisiensi besi. Penelitian di Israel digunakan kadar 
serum besi sebagai kriteria diagnosis. Penelitian di Swiss, selain digunakan reseptor transferin dan kadar feritin sebagai kriteria diagnosis, juga diperiksa kadar IL-6 dan hepsidin sebagai penanda inflamasi kronik derajat rendah.

Pada penelitian kami, hasil statistik tidak bermakna, tetapi ditunjukkan peningkatan kadar feritin pada subjek obes dibandingkan subjek non-obes dan hal ini sesuai dengan beberapa penelitian di luar negeri. Perbedaannya adalah pada penelitian di luar negeri peningkatan kadar feritin diikuti oleh kadar serum besi yang menurun, sedangkan pada penelitian kami kadar serum besi dalam batas normal pada kedua kelompok. Pada penelitian di luar negeri, peningkatan kadar feritin yang disertai dengan penurunan kadar serum besi disebabkan karena jaringan adiposit telah mengalami inflamasi kronik derajat rendah yang dibuktikan dengan meningkatnya kadar high sensitive - C Reactive Protein (hs-CRP) dan interleukin-6 (IL6). ${ }^{5,10,18}$ Kami tidak memeriksa kadar hs-CRP dan IL-6, tetapi melihat kadar serum besi yang masih normal kemungkinan pada subjek obes penelitian ini belum terjadi inflamasi kronik derajat rendah.

Inflamasi kronik derajat rendah juga menyebabkan sekresi hepsidin yang akan mengikat pembawa besi, yaitu feroportin-1 sebagai pembawa besi dari intrasel ke ekstrasel. Pengikatan ini menyebabkan retensi besi di enterosit dan sel retikuloendotelial sehingga kadar besi serum menurun. Namun demikian, feritin sebagai cadangan besi tubuh tidak dapat digunakan sehingga menyebabkan kadarnya meningkat di dalam darah. ${ }^{8,10}$ Pada penelitian ini, kami tidak memeriksa kadar hepsidin yang memegang peranan penting dalam defisiensi besi pada anak obesitas. Sekresi hepsidin terjadi ketika sel adiposit mengalami hiperplasia dan hipertrofi yang akan merangsang pelepasan sitokin IL-6. Hepsidin akan menghambat penyerapan zat besi dalam lumen usus dan retensi besi intraselular. Kami juga tidak mengevaluasi proses hiperplasia dan hipertrofi sel adiposit yang secara tidak langsung dapt dilihat dari peningkatan kadar hs-CRP., ${ }^{9,20}$

Kondisi saluran cerna juga memengaruhi penyerapan zat besi, gangguan saluran cerna, seperti penyakit radang usus dan penyakit seliak dapat mengganggu penyerapan zat besi. Infeksi cacing tambang dapat menyebabkan perdarahan sedikit demi sedikit yang mengarah pada defisiensi zat besi. ${ }^{21}$ Dalam penelitian kami, penyakit gangguan pencernaan dieksklusi dengan menggunakan anamnesis berupa riwayat diare atau manifestasi cacing saat buang air besar. Faktor lain yang memengaruhi status zat besi adalah aktivitas fisik. Remaja dengan aktivitas fisik yang tinggi membutuhkan asupan zat besi yang lebih tinggi, yang akan digunakan dalam pembentukan ATP dan transportasi oksigen. ${ }^{21,22}$ Kami tidak mengevaluasi aktivitas fisik kedua kelompok subjek. Penelitian menunjukkan aktivitas fisik yang tinggi dapat memperburuk derajat anemia, tetapi peranan aktifitas fisik tidak dievaluasi karena insiden defisiensi zat besi dan anemia defisiensi besi rendah. Oleh karena itu, diperlukan penelitian lebih lanjut tentang pengaruh aktivitas fisik terhadap insidens defisiensi zat besi pada remaja.

Kami menemukan bahwa asupan zat besi pada remaja obes dan non-obes lebih rendah daripada AKG. Jika masalah ini tidak cepat diselesaikan maka mereka akan berubah menjadi ADB sehingga terjadi peningkatan prevalensi ADB. ${ }^{2}$ Edukasi nutrisi mengenai kandungan makanan tinggi zat besi dan kebiasaan diet untuk meningkatkan penyerapan non-hem diperlukan untuk meningkatkan asupan zat besi harian.

Hasil penelitian kami mendukung Rekomendasi Satuan Tugas Remaja Ikatan Dokter Anak Indonesia tentang suplementasi zat besi untuk remaja. Program suplementasi zat besi untuk remaja membutuhkan dukungan dari semua pihak terkait, mulai dari tenaga medis hingga kementerian kesehatan untuk menyediakan distribusi sediaan besi yang merata dan berkesinambungan. ${ }^{23}$ Penelitian kami tidak dapat menyingkirkan efek peradangan kronis tingkat rendah pada subjek obesitas. Hal ini yang menyebabkan sulit melakukan analisis mengapa proporsi defisiensi zat besi lebih rendah terdeteksi pada kelompok remaja obes dibandingkan remaja yang non-obes.9,12,24

Penelitian kami hanya mengevaluasi asupan zat besi dan status gizi (diklasifikasikan dengan obesitas dan non-obesitas) sebagai faktor terkait dalam status zat besi. Oleh karena itu, diperlukan penelitian lebih lanjut untuk mengevaluasi pengaruh faktor lain terhadap kejadian defisiensi besi pada remaja obes.

\section{Kesimpulan}

Remaja obes usia 15-17 tahun mengalami defisiensi besi yang ditunjukkan dengan peningkatan kadar ferritin darah. Kadar serum besi yang masih dalam batas normal kemungkinan disebabkan karena subjek remaja obes belum mengalami inflamasi kronik 
derajat rendah sehingga diperkirakan tidak terjadi sekresi hepcidin yang dapat menghambat absorpsi besi di saluran cerna. Perlu penelitian lebih lanjut yang mengeksplorasi kejadian defisiensi besi pada anak remaja obes dengan terjadinya inflamasi kronik derajat rendah dan sekresi hepsidin.

\section{Daftar pustaka}

1. Kementerian Kesehatan Republik Indonesia. Riset kesehatan dasar. Jakarta: Badan Penelitian dan Pengembangan Kesehatan; 2013.

2. World Health Organization. Iron deficiency anaemia: assessment, prevention, and control: a guide for programme managers. Geneva: WHO;2001.h.33-114.

3. World Health Organization. Obesity: preventing and managing the global epidemic. WHO Technical Report Series 2000;894:18-20.

4. Ludwig DS. Childhood obesity: the shape of things to come. N Eng J Med 2007;27:416-8.

5. Hamies OP, Newfield RS, Koren I, dkk. Greater prevalence of iron deficiency in overweight and obese children and adolescents. Inter J Obes 2003;27:416-8.

6. Nead KG, Halterman JS, Kaczorowski M, dkk. Overweight children and adolescents: a risk group for iron deficiency. Pediatrics 2004;114:104-8.

7. Yanoff LB, Menzie CM, Denkinger B, dkk. Inflammation and iron deficiency in the hypoferremia of obesity. Int $\mathrm{J}$ Obes 2008;31:1412-9.

8. Miraglia E, Santoro N, Amato A, dkk. Hepcidin in obese children as a potential mediator of the association between obesity and iron deficiency. J Clin Endocrinol Metab 2009;94:5107.

9. Ganz T. Hepcidin and iron regulation, 10 years later. Blood 2011;117:4425-33.

10. Aeberli I, Hurrell RF, Zimmermann MB. Overweight children have higher circulating hepcidin concentrations and lower iron status but have dietary iron intakes and bioavailability comparable with normal weght children. Inter J Obes 2009;33:1111-7.

11. Sjarif DR. Obesitas anak dan remaja. Dalam: Sjarif DR, Lestari ED, Mexitalia M, Nasar SS, penyunting. Buku Ajar Nutrisi Pediatrik dan Penyakit Metabolik. Edisi pertama. Jakarta: Badan Penerbit Ikatan Dokter Anak Indonesia; 2011.h.23044 .
12. World Health Organization, Center for Disease Control and Prevention. Assesing the iron status of population. Geneva: WHO press 2007;2:1-107.

13. Menzie CM, Yanoff LB, Denkinger BI, dkk. Obesity-related hypoferremia is not explained by differences in reported intake of heme and non heme iron or intake of dietary factors that can affect iron absorption. J Am Diet Assoc 2008;108:145-8.

14. Kementerian Kesehatan Republik Indonesia. Peraturan Menteri Kesehatan Republik Indonesia nomor 75 tahun 2013: tunjangan diet yang direkomendasikan untuk orang Indonesia. Jakarta; 2013.

15. Wians FH, Urban JE, Keffer JH, dkk. Discriminating between iron deficiency anemia and anemia of chronic disease using traditional indices of iron status vs transferrin receptor concentration. Am J Clin Pathol 2001;115:112-8.

16. Gibson RS, Ferguson EL. Conducting the interactive 24-hours recall. Dalam: Gibson RS, Ferguson EL, penyunting. An interactive 24-hour recall for assessing the adequacy of iron and zinc intakes in developing countries. Edisi pertama. Washington DC: Harvest Plus; 2008.h.45-61.

17. Zijp I, Korver O, Tijburg LBM. Effect of tea and other dietary factors on iron absorption. Crit Rev Food Sci Nutr 2000;40:371-98.

18. Sharif MR, Madani M, Tabatabaie F. Comparative evaluation of iron deficiency among obese and non-obese children. Iran J Ped Hematol Oncol 2014;4:160-6.

19. Tam CS, Clement K, Baur LA, dkk. Obesity and lowgrade inflammation: a paediatric perspective. Obes Rev 2010;11:118-26.

20. Hernández HR, Mendía LES, Ramírez GR, dkk. Obesity and inflammation: epidemiology, risk factors, and markers of inflammation. Int J Endocrinol 2013;2013:1-5.

21. Camaschella C. Iron deficiency anemia. N Eng J Med 2015;372:1832-43.

22. Frazer DM, Anderson GJ. Iron imports, intestinal iron absorption and its regulation. Am J Physiol Gastrointest Liver Physiol 2005;289:631-5.

23. Ikatan Dokter Anak Indonesia. Pentingnya suplementasi besi untuk anak. Dalam: Gatot D, Idjradinata P, Abdulsalam M, penyunting. Rekomendasi IDAI: suplementasi besi untuk bayi dan anak. Edisi pertama. Jakarta: Badan Penerbit Ikatan Dokter Anak Indonesia; 2011.h.1-9.

24. Humphreys LT, Pusacioglu C, Nemeth E, dkk. Rethinking iron regulation and assessment in iron deficiency, anemia of chronic disease, and obesity: introducing hepcidin. J Acad Nutr Diet 2012;112:391-400. 